Professor Nutting's " Report as Chairman of the Committee on State Fauna" contained a number of additions to the known fauna of the State and notes on varied faunal relations among a number of species heretofore recognized. The additions, which embrace only Vertebrates, include two mammals, nineteen birds, five reptiles, one batrachian, and five fishes.

The "Significance of the Concealed Crests of the Tyrannidae" was the title of another paper by the same author and discussed very elaborately the origin and use of the bright colored crests of different members of the Flycatcher family. Considerable evidence was produced to show that they assist the birds in securing food by alluring insects within easy reach.

Professor L. H. Pammel presented papers on "Phænological Notes for 1892," "Relation of Frost to Certain Plants," "Notes on the Flora of Arkansas and Texas," and "Pollination of Cucurbits."

The second paper contained records of numerous obserrations on temperatures and effect on different kinds of vegetation. The third contained notes collected by the author during two trips in the region mentioned, and the third, which was accompanied by a number of very tine drawings illustrating the anatomy of the flowers of cucurbits, a number of observations with regard to the pollination of these plants.

Mr. F. C. Stewart presented a paper on " Palisade Cells and Stomata of Leaves," giving record of numerous examinations of leaves of various plants, and especially of different varieties of apple and presenting the conclusion that these factors have little relation to the resistance of the plants to climatic conditions. $\mathrm{Mr}$ Stewart also presented a "Key to the Identification of Weed seeds."

Mr. H. A. Gossard presented " A List of Insects that have been taken in Clover, in Iowa," with observations on a number of the different species. It includes a large proportion of the species that have been accredited to this plant heretofore and a number of species not hitherto accredited with feeding upon it.

Dr. W. B. Niles presented "Preliminary Observations on a Cattle Disease of Frequent Occurrence in Some Parts of Iowa." In this paper the symptoms of the disease were described, and a statement of efforts to secure cultures of organisms occurring in the diseased animals. Inoculations direct from diseased animals had produced similar symptoms and disease, but inoculations with pure cultures of any of the organisms isolated had so far given negative results.

Mr. F. Reppert presented some " Notes on the Flora of Muscatine," containing record of some plants which appear to be quite out of their normal range. He described the peculiar conditions of the locality where most of these exceptional plants have occurred and suggested that such plants had probabls been introduced there by the agency of such hirds as ducks or geese.

Mr. F. W. Mally presented a "List of the Tenthredinidæ of Iowa," preliminary to a more exhaustive study of this group in the State.

Professor Herbert Osborn and F. A. Sirrine in "Notes on Aphididæ" presented a list of about forty species that had not hitherto been recognized in the State and notes of the habits of a number of species, also a description of a new species.

Professor Osborn also read a paper "On the Life Histories of Certain Jassidae," giving in detail the life histories of Deltoceph. alus inimicus, Deltocephalus debilis, and some others, and mentioned their relation to economic treatment of these species.

He also presented some notes on the "Catalogue of Iowa Hemiptera," making some additions and corrections to preceding lists.

His talk on a collecting trip to southern Mexico contained observations on various points visited as far south as Isthmus of Tehuantepec and references to the native people and animals observed. The talk was illustrated with lantern views of scenery in the localities visited and views showing costumes of the natives, animals of the region, etc.

The Proceedings of the Academy are now published by the State, a bill for that purpose having passed the last Legislature, and theipapers presented at this meeting will be printed as soon as possible.

The officers for the current year are: President, L. H. Pammel, Ames ; first vice-president, C. O. Bates, Cedar Rapids; second vice-president, A. A Veblen, Iowa City; secretary-treasurer, Herbert Osborn, Ames; Executive Committee, the officers and S, Calvin, Iowa City; F. M. Witter, Muscatine, and H. W. Norris, Grinnell.

\section{UNUSUAL ABUNDANCE OF THE GROSBEAK IN EASTERN MASSACHUSETTS.}

BY J. H. Bowles, PONKapoag, mass.

Although considerable of a rambler. I have never until this year noticed the Pine Grosbeak (Pinicola canudensis) in this vicinity. The unusually cold weather that we have had this winter seems to have thoroughly disturbed them in their vorthern homes, as, for the last two weeks, they hare been around here in great numbers. The first that I noticed was a flock of six, on Dec. 19, which were feeding on cone-seeds in the top of a hemlock tree. Since then I have noticed flocks, almost erery day, ranging in numbers from three to seventeen, although small flocks of six or eight are most commonly seen. Only a rery few were in the full red plumage, most of them showing it on the head and rump only. Their flight is exceedingly graceful, consisting. of dips toward the ground, in the manner of a woodpecker, only not so much exaggerated, in which they utter from time to time a short, mellow whistle. They are seen principally feeding on the buds of maple, walnut, ash, and evergreen trees, and seem to be always hungry, which, I think, in a measure accounts for their extreme tameness, as they will allow a person to approach within a few feet of them without taking any notice. When feeding in the road, which they sometimes do, they will allow a team to come almost on top of them before flying to the side of the road, only to come back again as soon as the team has passed. I cannot help mentioning here that the trait of coming one winter and being absent the next is very common with some birds. The Snow Bunting (Plectrophanes nivalis), for instance, although seen in large numbers last winter, has not made its appearance once this year as far as I hare heard. Certainly it is not so plentiful, as last winter I saw a large number of flocks of from six to fifty and one flock of about one hundred and fifty. The red-bellied Nuthatch (Sitta Canadensis) and the Yellow Red-Poll Warbler (Dendroica palmarum) also, which were very common several winters ago, have been completely missing since that time.

\section{NOTES AND NEWS.}

Four courses of lectures are being given by the Department of Biology of Columbia College, in Room 11, Library Building, on successive Thursday evenings, at eight o'clock, beginning Nov. 10, 1892. They are designed for those who desire to keep abreast of the later advances in biology without entering any of the technical courses. A limited number of tickets for the entire course will be issued to persons not students on pasment of a small fee. Application should be made to the Secretary of the President, Columbia College. The course on the History of the Theory of Evolution, by Henry F. Osborn, Sc.D., Da Costa professor of biology, was finished Dec. 15. A course on The Cellular Basis of Heredity and Development, by Edmund B. Wilson, Ph.D., adjunct professor of biology, beginning Thursday, Jan. 12, will consist of : Introduction : Cellular Basis of the Living Body. The Germ-Cells: Sex and Fertilization. Cell Genesis and Division. Egg and Spermatozoön : The Preparation for Development. Physiology of the Individual Cell. Inter-Cellular Dynamics: Theories of Heredity. This course will be of the greatest interest, as the progress during the last two years in our knowledge of the cell is simply marvellous. Courses will follow on The Origin and Evolution of the Fishes, by Bashford Dean, Ph.D., instructor in Biology, and Amphioxus and Other Ancestors of the Vertebrates: by Arthur Willey, B.Sc., tutor in Biology. 


\section{Science}

UNUSUAL ABUNDANCE OF THE GROSBEAK IN EASTERN MASSACHUSETTS

J. H. Bowles

Science ns-21 (519), 19

DOI: $10.1126 /$ science.ns-21.519.19

ARTICLE TOOLS

PERMISSIONS http://science.sciencemag.org/content/ns-21/519/19.1.citation

http://www.sciencemag.org/help/reprints-and-permissions 